\title{
Distribution and Morphology of Ghrelin-Immunopositive Cells in the Liver of the African Ostrich
}

\author{
Distribución y Morfología de las Células Inmunopositivas \\ a la Gregina en el Hígado de Avestruz Africana
}

\author{
Jia-xiang, Wang; Peng, Li; Xiao-ting, Zhang \& Li-xun, Ye
}

JIA-XIANG, W.; PENG, L.; XIAO-TING, Z. \& LI-XUN, Y. Distribution and morphology of ghrelin-immunopositive cells in the liver of the african ostrich. Int. J. Morphol., 35(4):1285-1290, 2017.

SUMMARY: Ghrelin is the endogenous ligand for the growth hormone secretagogue receptor, and has been found in the liver of multiple vertebrates. While ghrelin has been identified in the gastrointestinal tract of African ostrich chicks, little is known regarding its distribution in the liver of the African ostrich. In the present study, the distribution and morphological characteristics of ghrelin-immunopositive (ghrelin-ip) cells in the liver of the African ostrich were investigated using immunohistochemistry. Our results indicate that the liver is divided into two sections: the capsule and the parenchyma, which comprises hepatic lobules and the hepatic portal area. The hepatic lobules include the central vein, hepatocellular cord, and the hepatic sinusoid. The hepatocellular cord is composed of hepatocytes, and Macrophagocytus stellatus (Kupffer cells) as well as endothelial cells reside within the hepatic sinusoid. ghrelin-ip cells were detected among both the Macrophagocytus stellatus and endothelial cells of the hepatic sinusoid in the African ostrich liver. In contrast, no ghrelinip cells were located within the hepatocytes or the hepatic portal area. These results clearly demonstrated the presence of ghrelin-ip cells in the liver of the African ostrich. Therefore, ghrelin may have a physiological function in the liver of the African ostrich.

KEY WORDS: African ostrich; Ghrelin; Liver; Immunohistochemistry.

\section{INTRODUCTION}

Ghrelin is a brain-gut peptide that was first isolated as an endogenous ligand for the growth hormone secretagogue receptor in the rat stomach (Kojima et al., 1999). This peptide is comprised of 28 amino acids with the unique feature of an n-octanoylated residue (serine-3) (Kojima et al., 1999). The numerous and diverse physiological roles of ghrelin consist of the stimulated pituitary release of growth hormone, increased food intake, mediation of energy homeostasis, enhanced gastrointestinal motility, and the regulation of systemic insulin levels and glycaemia (Kojima et al., 1999; Kirchner et al., 2012; Yada et al., 2014; Perello \& Dickson, 2015; Alamri et al., 2016). To date, molecular biological studies have revealed that ghrelin is widely conserved in both mammals and nonmammals (Kojima et al., 2008).

In non-mammalian vertebrates, the ghrelin peptide has been purified from stomach extracts, which has revealed that ghrelin immunoreactivity and mRNA expression are primarily detected in the stomach or intestine (Kaiya et al., 2002). However, the expression of ghrelin mRNA was also identified in various organs of non-mammalian vertebrates other than the stomach, and there appears to be a speciesspecific difference in ghrelin expression (Kaiya et al., 2008). In the liver, ghrelin mRNA is expressed in the hammerhead shark, goldfish, catfish and grass carp, but not in eel, rainbow trout, tilapia, bullfrog, turtle, or chicken (Kaiya et al., 2008; Feng et al., 2013). However, Ma et al. (2015) demonstrated that ghrelin mRNA was located primarily in the proventriculus, followed by the liver and other tissues in E18 chicken embryos. Ghrelin-immunopositive cells have also been found in the liver of chicken, Wanxi white geese, and Xinjiang donkeys (Fang et al., 2008; Wei et al., 2010; Zhang et al., 2015). However, in the African ostrich, the presence of ghrelin-ip cells had been previously examined only in the stomach, intestines, and cerebellum (Wang et al., 2009; Wang et al., 2012). Moreover, there have been no studies regarding the distribution of ghrelin-ip cells in the liver of the African ostrich. Therefore, in this study, the distribution and the morphological characteristics of ghrelinip cells in the liver were studied in detail using immunohistochemistry. 


\section{MATERIAL AND METHOD}

Animals. African ostriches (age, 8 months; weight, $70.68 \pm 2.25$ $\mathrm{kg}$ ) were used in this study. African ostrich $(2$ females and 2 males) were obtained from the Ostrich Research Institute of Yangtze University in Hubei Province, China, where feed and water were made available ad libitum. All of the birds were maintained in a heated room with slatted plastic floor and were fed a starter diet for postnatal days 7, which was formulated according to the specifications of the Elsenburg Ostrich Feed Database (Brand, 2010). All procedures were approved by the Animal Care and Welfare Committee of our Institute.

Tissue preparation. The ostriches were deeply anesthetized with $10 \%$ urethane (Caoyang Secondary Chemical Plant, Shanghai, China) at a dose of $1 \mathrm{~g} / \mathrm{kg} \mathrm{BW}$, and perfused initially with $1000 \mathrm{~mL}$ of $0.85 \%$ normal saline (containing $0.075 \%$ sodium citrate) and thereafter with $1500 \mathrm{~mL}$ of $4 \%$ paraformaldehyde phosphate-buffered solution $(0.1 \mathrm{~mol} / \mathrm{L}, \mathrm{pH}$ 7.4) at $4{ }^{\circ} \mathrm{C}$. The abdomen was cut open, and the liver was quickly removed,and gently flushed with $0.85 \%$ normal saline to remove the content, then be postfixed for more than $24 \mathrm{~h}$ with $4 \%$ paraformaldehyde. After immersion, the tissues were embedded in paraffin. Serial sections $(5 \mu \mathrm{m})$ were cut on with a Leica microtome (Nussloch Gmbh, Germany), 2 suit sections were prepared; one suit was stained by haematoxylin and eosin (H\&E) to observe the cytoarchitecture of liver; the other was stained by immunohistochemistry to observe the distribution, morphological characteristics of ghrelin-ip cells in the liver of the African ostrich .

Immunohistochemistry. Immunohistochemical detection of ghrelin-ip cells using rabbit anti-ghrelin was carried out by the streptavidin-biotin-peroxidase complex (SABC) method. The production and specificity of the anti-human ghrelin serum used in this study were previously reported (Wang et al., 2009). Immunohistochemical staining was performed according to the following procedure. The sections were deparaffinized with xylene and rehydrated with decreasing concentrations of ethanol, then treated with $3 \%$ hydrogen peroxide $\left(\mathrm{H}_{2} \mathrm{O}_{2}\right)$ to block endogenous peroxidase for $10 \mathrm{~min}$ at room temperature. After rinsing with distilled water, the sections were incubated with a citrate buffer (pH6.0) and placed in a microwave oven until the water boiled to fully expose the antigen. After rinsing with phosphate-buffered saline (PBS), the sections were incubated with $5 \%$ normal goat serum for $20 \mathrm{~min}$. After removing superfluous liquid, the sections were incubated with rabbit anti-ghrelin serum (BA1619; Boster Corporation,Wuhan,China) diluted 1:100 in PBS for $12 \mathrm{~h}$ in a humid chamber at $4{ }^{\circ} \mathrm{C}$. After washing with PBS for 6 min, a second incubation with biotin-conjugated anti-rabbit IgG serum (SA1022; Boster Corporation, Wuhan,China) was carried out for $20 \mathrm{~min}$, and this was followed by further washing with PBS. Finally, the sections were incubated for 20 min with an SABC solution prepared according to the manufacturer's instructions. After washing with PBS for 20 min, the sections were reacted in a diaminobenzidinetetrachloride kit (DAB kit, AR1022, Boster Corporation,Wuhan, China) for $30 \mathrm{~min}$ to detect immunereactivity. After washing with distilled water, the sections were dehydrated with a graded ethanol series, cleared in xylene, mounted with a coverslip, and viewed under a light microscope (BH-2; Olympus, Japan). All of the incubations were carried out in a humid chamber at room temperature. Control sections were prepared using the same method, omitting the primary antibody. To examine the specificity of rabbit anti-human ghrelin antiserum, the diluted antiserum (1:100) was incubated with human ghrelin $(5 \mathrm{mg} / \mathrm{ml})$ at room temperature for $10 \mathrm{~h}$, and mixtures were centrifuged at $12000 \mathrm{rpm}$ for $25 \mathrm{~min}$ at 4 ${ }^{\circ} \mathrm{C}$. The supernatant was used as the primary antiserum for control tests.

Morphometric analysis. For each liver tissue sample, 3 crosssections were prepared after the samples had been stained with hematoxylin and eosin and SABC stain. Further, for each liver cross-section, 10 intact, well-oriented units were selected for experiments conducted in triplicate (30 measurements for each sample). After taking digital photographs under a light microscope with a digital camera (COOLPIX4500; Nikon, Japan).

\section{RESULTS}

The results presented are those obtained from both female and male chicks; no gender-specific effects were observed.

Cytoarchitecture of the liver in the African ostrich. The liver of the ostrich was reddish brown and contained no gall bladder. Moreover, the liver was divided into two sections: the outer membrane; and the inner parenchyma. The membrane was composed of the surface serosa and deep connective tissue, while the parenchyma was composed of the hepatic lobule and portal area (Figs. 1A and B). Since the interlobular connective tissue of African ostrich was underdeveloped, the hepatic lobule boundaries were not obvious (Fig. 1A). In contrast, the connective tissue in the portal area was relatively well developed; thus, the portal area was very obvious (Fig. 1B). The hepatic lobule was composed of the central vein, hepatic plate, and hepatic sinusoid (Fig. 1A); the central vein was the smallest branch of the hepatic vein (Fig. 1A). Moreover, the hepatic plate was composed of the hepatocytocellular cord, which consisted of two forms: two 
to seven hepatocytes that were in a clustered arrangement; and two layers of hepatocytes surrounding the central vein, forming a radiating shape (Fig. 1C). The hepatocytes were polygonal and large in volume, the nucleus was large and round and located in the center of the cell or off to one side. In addition, there were typically one or two nuclei in each hepatocyte, and the cytoplasm was dense and acidophilic (Fig. 1C). Lacuna among the hepatocellular cords formed the hepatic sinusoid, which varied in size. The sinus wall consisted of discontinuous endothelial cells, the absence of a basement membrane. Moreover, the nucleus was flat and convex towards the sinus cavity (Fig. 1D). In addition, there were
Macrophagocytus stellatus (Kupffer cells) among the endothelial cells, which exhibited an extensive cytoplasm, irregular shape, large nucleus and cell body; the majority penetrated into the vascular sinus (Fig. 1D). Moreover, blood cells were also observed in the cavity of the hepatic sinusoid (Fig. 1C). Bile canaliculus was formed by the edge on both sides of the adjacent hepatocytes, spreading over the liver parenchyma, and expanded into cellular gaps (Fig.1D). At the junction of hepatic lobule, the portal area of the interlobular connective tissue was observed, and could be further divided into an interlobular vein, the interlobular arteries, and interlobular bile duct (Fig. 1B).
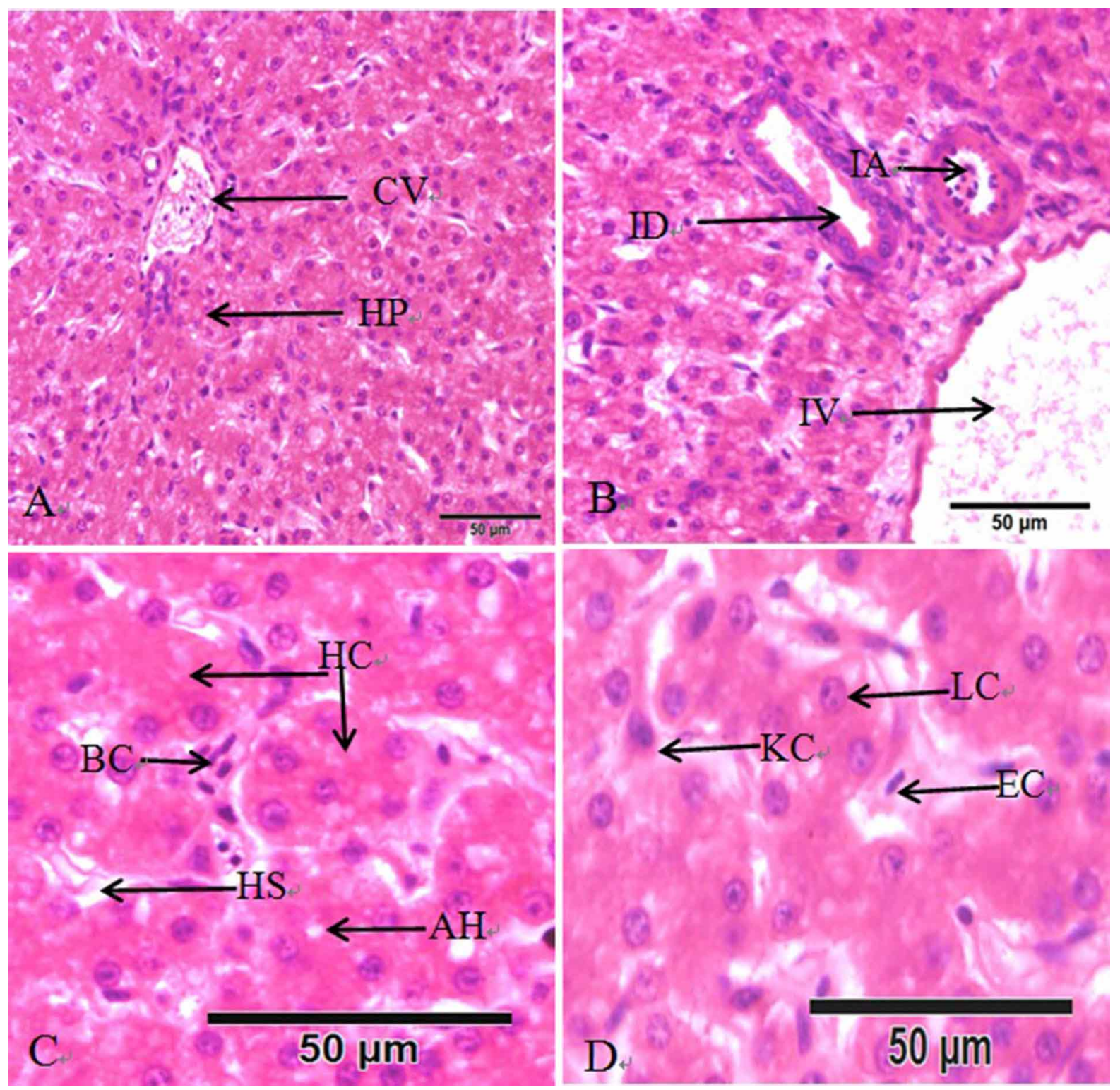

Fig. 1. Photomicrographs of the histological observations in the liver of the African ostrich (HE staining). (A) The hepatic lobule. (B) The portal area. (C) The hepatic plate. (D) The hepatic plate. (CV, central vein; HP, hepatic plate; IA, interlobular arteries; IV, interlobular vein; ID, interlobular bile duct; HC, hepatocytes cord; BC, blood cell; HS, hepatic sinusoid; AH, bile canaliculus; LC, hepatocyte; KC, Kupffer cell; EC, endothelial cell). Scale bar: $50 \mu \mathrm{m}$. 
Distribution of ghrelin-immunopositive cells. Ghrelin-ip cells were found within the hepatic sinusoid; there are no ghrelin-ip cells among the hepatocytes and the hepatic portal area in the African ostrich liver (Figure. 2A). In the hepatic sinusoid, the endothelial cells were stained for the presence of ghrelin, and long fusiform ghrelin-ip cells were observed (Fig. 2B); the Kupfer cells also stained positive for ghrelin, and irregular shaped ghrelin-ip cells were observed. The cells exhibited large cell bodies and the majority penetrated into the vascular sinus (Fig. 2C). The results of the control tests using antiserum absorbed with $5 \mathrm{mg} / \mathrm{mL}$ ghrelin revealed the complete disappearance of immunoreactivity in the liver (Fig. 2D).
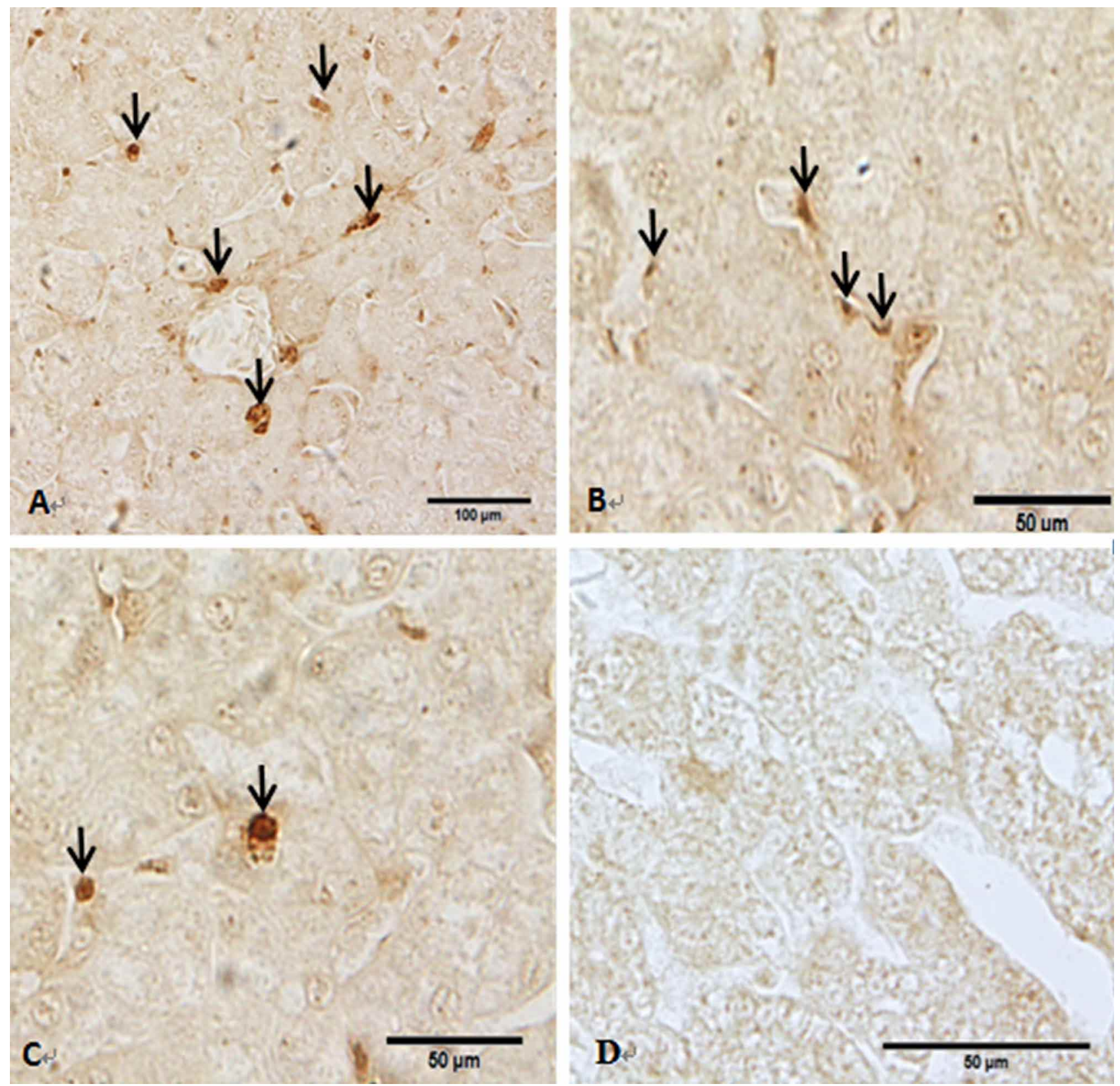

Fig. 2. Photomicrographs of the ghrelin-immunopositive cells in the liver of the African ostrich (SABC staining). (A) A large number of ghrelin cells (arrows) were found within the hepatic sinusoid. (B) Ghrelin-ip cells (arrows) surrounding the endothelial cells of the hepatic sinusoid. (C) Ghrelin-ip cells (arrows) within the Kupffer cells of the hepatic sinusoid. (D) Photomicrograph of the absorption testing in the liver. HC, hepatocytes cord. (A) Scale bar: $100 \mathrm{~mm}$; (B-D) Scale bar: $50 \mathrm{~mm}$. 


\section{DISCUSSION}

The liver is an important digestive gland and detoxification organ in the body, the structure of which differs between species. In the present study, we found that the liver of the African ostrich was divided into two parts: the capsule and the parenchyma. The parenchyma was further divided into multiple hepatic lobules surrounding the capsule; however, the hepatic lobules were not obvious, the hepatic portal area was highly prevalent. These results are similar to that of Chroysolophus pictus (Zhang et al., 2002), Syrrhaptes paradoxus (Wang et al., 2013), and Wanxi White Geese (Fang et al., 2005); however, the hepatic lobules of the duck (Luo, 1983) are extremely obvious, which differs from the African ostrich. These results indicate that the extent of the connective tissue and the prominence of the hepatic lobules are remaining differences between various bird species.

In Chroysolophus pictus, the hepatocellular cord consisted of two layers of hepatocytes, and those surrounding the central vein lines formed a radiating shape (Zhang et al., 2002). In the Wanxi White Geese, the hepatocellular cord was comprised of one layer of hepatocytes and those surrounding the central vein lines formed a radiating shape (Fang et al., 2005). However, in the African ostrich, the hepatocellular cord has two forms: 1) two to seven hepatocytes that form a clustered arrangement; and 2) two-layers of hepatocyte, that surround the central vein lines and form a radiating shape. These structures are similar to that of Syrrhaptes paradoxus (Wang et al., 2013). These results further suggest that there is variability in the arrangement of hepatocytes between different animals. In this study, we also found that the wall of the hepatic sinusoid consists of one layer of endothelial cells that was not continuous. In addition, the endothelial cells contain no basement membrane and the gap between the endothelial cells is relatively large. These findings are similar to that of Syrrhaptes paradoxus (Wang et al., 2013) and suggest that macromolecules can enter into Dili's space and provide nutrients to the hepatocytes.

In chickens, ghrelin-ip cells have been identified in the Macrophagocytus stellatus (Kupffer cells) of the liver; however, they have not been observed among the endothelial cells or phepatocytes (Wei et al., 2010). In the Wanxi white goose, ghrelin-ip cells were found primarily in the hepatocyte and lymphoid tissues (Fang et al., 2008). Moreover, in the Xinjiang donkey, a larger number of ghrelin-ip cells were found residing within the hepatic lobules and were occasionally identified in the hepatic portal area (Zhang et al., 2015). In the present study, ghrelin-ip cells were detected in both the Macrophagocytus stellatus (Kupffer) and endothelial cell populations of the hepatic sinusoid in the African ostrich liver.
In addition, there was an absence of ghrelin-ip cells in the hepatocellular cord and hepatic portal area, which differs from that of chicken, geese, and Xinjiang donkey (Fang et al., 2008; Wei et al., 2010; Zhang et al., 2015).

Recently, Sun et al. (2015) revealed that Macrophagocytus stellatus (Kupffer cells) were involved in the regulation of the inflammatory response in the liver of the human. Moreover, Stasi \& Milani (2016) also revealed that acylated ghrelin has anti-inflammatory functions that are dependent on the direct effect of $\mathrm{T}$ lymphocytes and monocytes; in particular, ghrelin inhibits the expression of proinflammatory cytokines, such as interleukin-1 $\beta$ (IL-1 $\beta$ ), interleukin-6 (IL-6), and tumor necrosis factor (TNF- $\alpha$ ). Azizzadeh et al. (2016) demonstrated that ghrelin is effective for reducing the intensity of both the early and late phases of inflammatory-mediated pain. Therefore, it appears that ghrelin exerts its analgesic effects in part by increasing the serum levels of anti-inflammatory cytokines. Furthermore, Bianchi et al. (2016) also demonstrated that the administration of ghrelin significantly reduced post-surgical adhesions via the downregulation of pro-inflammatory gene and protein expression; this suggests the potential use of ghrelin for the prevention of post-operative adhesion.

In the present study, ghrelin-ip cells were detected in the Macrophagocytus stellatus (Kupffer cells) of the liver. These results suggest that ghrelin may play a role in regulating inflammation within the liver. However, the specific relationship between the distribution and function of ghrelinip cells in the liver of the African ostrich requires further research.

\section{CONCLUSION}

In conclusion, it is now clear that the liver of the African ostrich has its own unique characteristics: the hepatic lobules were not obvious, while the hepatic portal area was highly prevalent; the hepatocellular cord has two forms: 1) two to seven hepatocytes that form a clustered arrangement; and 2) two-layers of hepatocyte, that surround the central vein lines and form a radiating shape; the wall of the hepatic sinusoid consists of one layer of endothelial cells that was not continuous. The ghrelin-ip cells were detected in both the Macrophagocytus stellatus (Kupffer) and endothelial cell populations of the hepatic sinusoid in the African ostrich liver. In addition, there was an absence of ghrelin-ip cells in the hepatocellular cord and hepatic portal area. Because that Macrophagocytus stellatus (Kupffer cells) were involved in the regulation of the inflammatory response in the liver of the human. Thus, these findings indicate that the role of 
ghrelin in the African ostrich liver may have a physiological function, and ghrelin may be involved in the inflammatory response of the liver. Therefore, more research is needed to gain a better understanding of the effects of ghrelin on perinatal growth and development in the liver of the African ostrich.

ACKNOWLEDGEMENTS. We would like to thank the National Natural Science Foundation Project of China. This work was supported by the National Natural Science Foundation Project of China, No.31402152.

JIA-XIANG, W.; PENG, L.; XIAO-TING, Z. \& LI-XUN, Y. Distribución y morfología de las células inmunopositivas a la ghrelina en el hígado de avestruz africana. Int. J. Morphol., 35(4):1285-1290, 2017.

RESUMEN: La ghrelina es el ligando endógeno para el receptor secretagogo de la hormona del crecimiento, y se ha encontrado en el hígado de múltiples vertebrados. A pesar que la ghrelina ha sido identificada en el tracto gastrointestinal de polluelos de avestruz africanas, poco se sabe sobre su distribución en el hígado de esta ave. En el presente estudio se investigó la distribución y características morfológicas de las células ghrelininmunopositivas (ghrelin-ip) en el hígado del avestruz africana mediante inmunohistoquímica. Nuestros resultados indican que el hígado se divide en dos secciones: la cápsula y el parénquima, que comprende los lóbulos hepáticos y el área portal hepática. Los lóbulos hepáticos incluyen la vena central, el cordón hepatocelular y el sinusoide hepático. El cordón hepatocelular está compuesto de hepatocitos y de Macrophagocytus stellatus (células de Kupffer) y las células endoteliales se localizan dentro del sinusoide hepático. Fueron detectacas células ghrelin-ip entre los Macrophagocytus stellatus y las células endoteliales del sinusoide hepático en el hígado de avestruz africana. En contraste, no se localizaron células de ghrelin-ip dentro de los hepatocitos o en el área portal hepática. Estos resultados demuestran claramente la presencia de células de ghrelin-ip en el hígado. Por lo tanto, la ghrelina puede tener una función fisiológica en el hígado de avestruz africana.

PALABRAS CLAVE: Avestruz africana; Grelina; Hígado; Inmunohistoquímica.

\section{REFERENCES}

Alamri, B. N.; Shin, K.; Chappe, V. \& Anini, Y. The role of ghrelin in the regulation of glucose homeostasis. Horm. Mol. Biol. Clin. Investig., 26(1):311, 2016.

Azizzadeh, F.; Mahmoodi, J.; Sadigh-Eteghad, S.; Farajdokht, F. \& Mohaddes, G. Ghrelin exerts analgesic effects through modulation of IL-10 and TGF-b Levels in a rat model of inflammatory pain. Iran. Biomed. J., 21(2):114-9, 2017.

Bianchi, E.; Boekelheide, K.; Sigman, M.; Lamb, D. J.; Hall, S. J. \& Hwang, K. Ghrelin inhibits post-operative adhesions via blockage of the TGF-b signaling pathway. PLoS One, 11(4):e0153968, 2016.

Brand, T. S. Elsenburg Ostrich Feed Databases. Elsenburg, Elsenburg Agricultural Research Centre, 2010.

Fang, F. G.; Li, M. Q.; Tao, Y.; Jiang, Sh. D. \& Li, F. B. Immunohistochemical localization of ghrelin in the liver and pancreas of adult Wanxi white goose. Chin. J. Anat., 31(1):28-30, 2008.

Fang, F. G.; Wu , J. J.; Li, F. B.; Yu, J. P.; Zhang, L. X. \& Jiang, Sh. D. Morphologic study on digestive gland in adult female Wanxi white geese. J. Anhui Agric. Sci., 33(2):287-9, 2005.

Fang, F. G.; Wu, J. J.; Li, F. B.; Yu, J. P.; Zhang, L. X. \& Jiang, Sh. D. Molecular cloning, tissue distribution, and ontogenetic expression of ghrelin and regulation of expression by fasting and refeeding in the grass carp (Ctenopharyngodon idellus). J. Exp. Zool. A Ecol. Genet. Physiol., 319(4):202-12, 2013

Kaiya, H.; Miyazato, M.; Kangawa, K.; Peter, R. E. \& Unniappan, S. Ghrelin: a multifunctional hormone in non-mammalian vertebrates. Comp. Biochem. Physiol. A Mol. Integr. Physiol., 149(2):109-28, 2008.

Kaiya, H.; Van der Geyten, S.; Kojima, M.; Hosoda, H.; Kitajima, Y.; Matsumoto, M.; Geelissen, S.; Darras, V. M. \& Kangawa, K. Chicken ghrelin: purification, cDNA cloning, and biological activity. Endocrinology, 143(9):3454-63, 2002.

Kirchner, H.; Heppner, K. M. \& Tschöp, M. H. The role of ghrelin in the control of energy balance. Handb. Exp. Pharmacol., (209):161-84, 2012.

Kojima, M.; Hosoda, H.; Date, Y.; Nakazato, M.; Matsuo, H. \& Kangawa, K. Ghrelin is a growth-hormone-releasing acylated peptide from stomach. Nature, 402(6762):656-60, 1999.

Kojima, M.; Ida, T. \& Sato, T. Structure of mammalian and nonmammalian ghrelins. Vitam. Horm., 77:31-46, 2008.

Luo, K. Poultry Anatomy and Histology. Fuzhou, Fujian Science and Technology, 1983. pp.50-76.

Ma, J. Y.; Yu, Y.; Xue, J. J.; Ou, Ch. B.; Mo, H. Zh. \& Liu, X. Y. Tissue distribution and developmental changes of ghrelin and GOAT expression in broiler chickens during embryogenesis. Gen. Comp. Endocrinol., 213:130-5, 2015.

Perello, M. \& Dickson, S. L. Ghrelin signalling on food reward: a salient link between the gut and the mesolimbic system. J. Neuroendocrinol., 27(6):42434, 2015.

Stasi, C. \& Milani, S. Functions of ghrelin in brain, gut and liver. CNS Neurol. Disord. Drug Targets, 15(8):956-63, 2016.

Sun, H. W.; Li, Ch. L.; Wang, P. \& Cui, Y. Recent advances in kupffer cells. Chin. J. Hepatobiliary Surg., 21(5):351-3, 2015.

Wang, J. X.; Li, P. \& Zhou, Y. Distribution and morphology of ghrelinimmunopositive cells in the cerebellum of the African ostrich. Tissue Cell., 44(6):373-7, 2012

Wang, J. X.; Peng, K. M.; Liu, H. Zh.; Song, H.; Chen, X. \& Liu, M. Distribution and developmental changes in ghrelin-immunopositive cells in the gastrointestinal tract of African ostrich chicks. Regul. Pept., 154(1-3):97$101,2009$.

Wang, Y.; Yin, H. Y.; Ma, Zh. L. \& Wang, X. F. Microscopic Observation on Several Tissues and Organs of Syrrhaptes Paradoxus. Acta High Teach. Gansu, 18(2):69-73, 2013.

Wei, F. M.; Li, Y. G.; Ye, Y. L.; Zhang, Y.; Ma,Y. J. \& Jiang, Q. Y. Localization and development of ghrelin-immunopositive cells in periphery organs of broiler chickens. Acta Vet. Zootech. Sin., 41(3):341-6, 2010.

Yada, T.; Damdindorj, B.; Rita, R. S.; Kurashina, T.; Ando, A.; Taguchi, M.; Koizumi, M.; Sone, H.; Nakata, M.; Kakei, M. \& Dezaki, K. Ghrelin signalling in b-cells regulates insulin secretion and blood glucose. Diabetes Obes. Metab., 16 Suppl. 1:111-7, 2014.

Zhang, D. L.; Yu, Sh. Y.; Liu, Sh. Q. \& Hu, Ch. X. The histological observation of the liver in Chroysolophus pictus. J. Jiangxi Norm. Univ. (Nat. Sci. Ed.)., 38(2):61-3, 2002

Zhang, M. K.; Fan, X. N.; Wei, L.; Zhang, Z. Q. \& Zhu, X. M. The histological observation on the liver and pancreas with the distribution of ghrelin in Xinjiang donkey. Heilongjiang Anim. Sci. Vet. Med., 8:25-8, 2015.

\section{Corresponding author:}

Jia-xiang Wang

Department of Anatomy

Histology and Embryology,

College of Animal Science

Yangtze University,

1 Nanhuan Road

Jingzhou, Hubei

P. R. CHINA

E-mail: Wangjiaxiang1109@163.com

Received: 23-05-2017

Accepted: 05-09-2017 